As migration is westward, with Austria being the destination country among the neighbouring countries, learning about the educational policies and opportunities for school progression in Austria is vital for migratory movements, and exploring differences in educational terminology is a useful linguistic-sociolinguistic exercise.

Keywords: educational terms, Termini Hungarian-Hungarian dictionary, Termini Hungarian Language Research Network, education systems

\title{
Ízelítők a Termini magyar-magyar szótár kárpátaljai anyagából
}

\section{Bevezetés}

Húsz évvel ezelőtt, 2001-ben jött létre a Magyarországgal szomszédos államokban müködő magyar nyelvészeti kutatóhelyek hálózata, a Termini Kutatóhálózat (Péntek 2009). ${ }^{7}$ 2011-ben, a kutatóhálózat fennállásának első kerek, tizedik évfordulóján reprezentatív kötetben mutattuk be, kik vagyunk, mivel foglalkozunk (Benő-Péntek szerk. 2011). Amint a Magyar Nyelvőr jelen számában fentebb közölt tanulmányokból is kiderül, a közös kutatási programok egyike a Magyarországon kívül beszélt és írott magyar nyelvváltozatok sajátos szókészleti elemeinek gyűjtése, rendszerezése, elemzése. A 2007 óta online is elérhető szótárunkba ${ }^{8}$ azokat a magyarországiaktól eltérö, idegen eredetü (az adott régió magyar nyelvhasználatában rendszerint az államnyelvből származó vagy kontaktushatásra visszavezethető) szavakat, szójelentéseket gyüjtjük össze, amelyeket a Kárpát-medencében, Magyarország határain túl élő őshonos magyar kisebbségi közösségekben használnak. A kizárólag valamely Magyarországgal szomszédos államban használt szavak, szókapcsolatok mellett azokat a lexémákat is gyüjtjük az adatbázisba, amelyek Magyarországon is használatosak, de más jelentésben (Lanstyák-Benő-Juhász 2011; Benő-Juhász-Lanstyák 2020).

Mivel ez az online szótári adatbázis a magyarral a Kárpát-medencében érintkező számos nyelvből (főként a Magyarországgal szomszédos országok államnyelveiből, többségi nyelveiből: szlovák, ukrán, orosz, román, szerb, horvát, szlovén, német) tartalmaz (föként) közvetlen kölcsönszókat, az adatbázis a magyar és az indoeurópai nyelvek közötti kontaktusok vizsgálatának gazdag forrása. Mivel nem papíralapú, hanem internetes szótári adatbázisról van szó, az egyes szócikkek szerkesztése során gyakorlatilag nincsenek terjedelmi korlátok, így a sok élőnyelvi példamondat, a bő kontextus lehetővé teszi a jelentésárnyalatok elkülönítését, a stílusminősítések pontosítását. A könnyen kereshető adatbázisban a címszavak számos szempont szerint listázhatók: régió, stílusminősítés, átadó nyelv, szófaj, fogalomkör stb.

7 http://termini.nytud.hu/

8 http://termini.nytud.hu/htonline/htlista.php?action=firstpage 


\section{Azonosságok és különbségek: néhány példa}

Az online szótári adatbázis elemzése alapján kiderül, hogy számos olyan kölcsönszó használatos a Magyarországgal szomszédos országok magyar nyelvváltozataiban, amelyek nem csupán egy, hanem több régióban is ismertek. Így például a pólóing, illetve ujjatlan sporting megnevezésére több régióban találunk hasonló szavakat: $\mathrm{Er}^{3}$ majó 'ujjatlan sporting, trikó', Ka májka 'ua', Va, Hv majica 'pólóing, atlétatrikó'; Mv májca 'pólóing'. A különféle üdítöitalok neve is hasonló a legtöbb régióban: Er szukk 'üdítöital', 'szörp', Ka szok 'gyümölcslé', Mv szok 'gyümölcslé, üdítőital, szörp', Hv szók és Va szokk 'gyümölcslé, üdítöital, szörp'.

Egy-egy esetben előfordulnak több (öt, hat, hét) régióra kiterjedő teljes hangalaki és jelentésbeli azonosságok is a közvetlen kölcsönszavak között. Például Er, Fv, Öv, Va, Hv, Mv cirkula 'körfürész'; Fv, Va, Hv, Mv, Ka szesztra '(kórházi) növér, ápolónő'; $\mathrm{Fv}, \mathrm{Va}, \mathrm{Hv}, \mathrm{Mv}$, Öv, Ka tunel 'alagút'; Fv, Va, Hv, Mv, Ka vetrovka '(szél)dzseki' stb. Annak a betegségnek a megnevezésében pedig, amelyet Magyarországon influenzaként ismernek, inkább a magyarországi magyarok számítanak kivételnek, hiszen ezt minden szomszédos államban nagyjából hasonlóan nevezik meg a magyarok: Er, Va, Hv, Mv gripa, Ka gripp, Öv grippe, Fv chripka (standard magyar: influenza). Hasonló mondható el a minden Magyarországgal szomszédos állam magyar közösségeiben szeminárként megjelenő, 'szeminárium; továbbképző tanfolyam' jelentésben előforduló lexémáról: csak a magyarországi magyarok körében nem használatos a szó ebben a hangalakban.

Több olyan lexéma is szerepel az online szótári adatbázisban, amelyek azonos hangalakúak ugyan, ám más-más jelentés kapcsolódik hozzájuk az egyes régiókban. A ht-listában szereplő blokk szónak például a következő jelentéseit találhatjuk:

1) Fv, Va, Ka, Hv, Mv, Öv '(lakótelepi) panelház, tömbház';

2) Ka 'karton (cigaretta)';

3) Va, Hv 'agyagból égetett üreges építőelem'.

A 2007-ben Budapesten kiadott idegen szavak szótára (Tolcsvai Nagy szerk. 2007: 137) tartalmazza a blokk szó fenti jelentéseit, és ezek mellett további 13 jelentést ad meg. A fenti három jelentésnél a közmagyar szótár jelzi, hogy ezek a jelentések csak a magyar nyelv jelzett állami változataiban fordulnak elő.

\section{Néhány példa a szótár kárpátaljai anyagából}

A folyamatosan bővülő online szótári adatbázisban 2021 októberében 880 olyan szócikk található, amelyben szerepel a $K a$ rövidítés, vagyis ennyi olyan szót, szókapcsolatot, jelentést regisztrál a szótár, amelyek előfordulnak a kárpátaljai magyar nyelvhasználatban (is).

3 Az egyes rövidítések az alábbi országokban élő magyar közösségeket jelölik: Fv: Felvidék, Szlovákia; Ka: Kárpátalja, Ukrajna; ER: Erdély, Románia; Va: Vajdaság, Szerbia; Hv: Horvátország; Mv: Muravidék, Szlovénia; Őv: Örvidék, Ausztria; HU: Magyarország. 
A több régióban elöforduló kölcsönszavak mellett természetesen számos olyan szó is használatos Kárpátalján, amelyek csak a magyar nyelvterület ezen részén ismertek. Ezeknél elsősorban az orosz (hiszen Kárpátalja 1945 és 1991 az orosz nyelvet preferáló Szovjetunió része volt) és az ukrán az átadó nyelv. Ezek a szavak jelentős részben olyan fogalmak, tárgyak, intézmények stb. megnevezésére szolgálnak, amelyeket a kárpátaljai magyar beszélők a magyar nyelvterület több államba szakadása előtt nem (nagyon) ismertek (Lanstyák 2008: 123). Ilyen például a 'a szovjet (és az utódállamok) hadseregében az idős katonáknak a fiatalokkal szembeni kegyetlen bánásmódja' jelentésben ismert, orosz eredetü gyedovcsina. Figyelemre méltó, hogy a szlovákiai magyar nyelvhasználatban hasonló jelentésben ('hadseregben, kollégiumban fiatalabbak, gyengébbek zaklatása') ismert a sikanéria lexéma.

Vannak azonban olyan elemek is az online szótári adatbázis kárpátaljai felségjelzésü részében, amelyek szorosan kapcsolódnak a 2004-es narancsos forradalom, illetve a 2014-es méltóság forradalma után felgyorsult társadalmi, politikai, közigazgatási átalakulásokhoz, valamint a 2014 tavaszán kitört kelet-ukrajnai fegyveres konfliktus eseményeihez.

Az egy évtizednyi különbséggel egymást követő két ukrajnai forradalom során egyaránt központi, szimbolikus szerepet játszott az a tér, ahol az események nagy része történt: az ukrán főváros ukránul Майдан незалежності, azaz Függetlenség tere nevet viselő közterülete. A forradalmakról szóló hírek és tudósítások révén a tér nevéből köznevesült a majdan lexéma, amely ma már nemcsak a kijevi föteret, hanem az ott lezajlott eseményeket is jelenti, amint ez a Termini magyar-magyar szótárban a majdan szócikkben található példamondatból is kitünik: „,Nagyszabású, véres cirkusz a köztereken ide, háború Donbászban oda, a pénzpumpa ugyanúgy müködött tovább. A majdanok kifutása tovább erösíti a fenti felfogást."

Az ukrajnai politikai válságok sorozatához köthető két további tulajdonnév köznevesülése: a tyituska és a porohobot. A tyituska fónév azokat a (rendszerint jó fizikumú, fiatal) személyeket jelöli, akik megfelelő fizetség fejében felbérelhetők, hogy politikai tüntetéseken vegyenek részt, vagy zavarkeltést provokáljanak a politikai ellenfelek nyilvános (kampány)rendezvényein. A tyituska köznév egy Vagyim Tyituska nevü bilacerkvai személy nevéből köznevesült, aki politikai megrendelésre támadt ellenzéki újságírókra. A negatív jelentéstartalmú lexéma ma már általában jelöl minden, politikai eseményeken rendbontást kezdeményező személyt, mint ebben a példamondatban: „Sportos külsejü emberek egy csoportja kezdetben elállta Hricenko útját, majd a politikust kísérö híveire támadt. Néhányat közülük a »tyituskák « megvertek".

A porohobot lexéma a 2019-es ukrajnai elnökválasztások előtti időszakban jelent meg az ukrán politikai szakzsargonban és a politikai újságírásban, majd onnan átkerült a kárpátaljai magyar lapok, hírportálok szókincsébe is. A porohobot Petro Porosenko ukrajnai politikus nevéből alakult, és az egykori elnök feltétlen híveit, politikai aktivistáit, pártjának tagjait jelöli, mint például ebben a példamondatban: „, Az utóbbinak különösen azért van nagy jelentösége, mivel az ellenzéki párt és maga Porosenko is jelentös médiával rendelkezik, lásd a Prjamij és a Pjatij tévécsatornákat, valamint a »szövetséges « Eszpresszót, továbbá a lojális szakértők, bloggerek és egyéb világhálós irogatók hálózatát, akiket a köznyelv porohobotokként emleget”. 
Több olyan szó is megjelenik a magyar-magyar online szótárban, amelyek a kelet-ukrajnai fegyveres konfliktushoz kapcsolódnak. Ilyen például az ukrán Антитерористична операйія szószerkezetböl létrejött, 'antiterrorista operáció, terrorellenes hadművelet' jelentésben használt $A T O$ mozaikszó, amely a 2014 áprilisában a kelet-ukrajnai Donyeck és Luhanszk megyék területén kirobbant, több ezer áldozatot követelő fegyveres konfliktus megnevezésére szolgál. Ebböl jött létre az $A T O$-s melléknév és főnév, amely egyrészt az ATO-val kapcsolatos fogalmak, tárgyak, események jelzöje (például: ATO-s veszteség, ATO-s múzeum, ATO-s veterán), másrészt azokat a fegyvereseket jelöli, akik az ukrán kormányerők oldalán vettek, vesznek részt a harcokban.

\section{Egy törvény - több címszó}

Közhely, hogy a szókészlet változásai szorosan és gyorsan követik a társadalmi átalakulásokat. Egy ukrajnai törvény és az általa elöírt közigazgatási reform következményeként például több új címszó jelent meg a Termini magyar-magyar szótárában.

Ukrajnában a Verhovna Rada (a parlament) 2015-ben fogadta el az Önkormányzatok önkéntes egyesüléséröl szóló törvényt, amellyel kezdetét vette az ukrán közigazgatási reform, amelyet decentralizáció néven emlegetnek az ukrán sajtóban, és így került az ukrán децентралізайія megfelelöjeként a kárpátaljai magyar nyelvhasználatba a decentralizáció lexéma. Bár az Osiris Idegen szavak szótára (lásd Tolcsvai Nagy szerk. 2007: 208) tartalmaz decentralizáció szócikket, abban 'a döntések minél alacsonyabb szintre helyezése egy intézményen belül' jelentés szerepel. A kárpátaljai magyar nyelvhasználatban azonban a decentralizáció 'a járások öszszevonását, illetve korábban önálló települési önkormányzatok nagyobb, több egységből álló önkormányzati társulásokba való egyesítését eredményező közigazgatási reform' jelentésben használatos.

A jogszabályban elöírt közigazgatási reform során Ukrajnában számos járást vontak össze, illetve a helyi városi és falusi önkormányzatoknak társulás révén úgynevezett kistérségekbe (hromada vagy OTH) kellett szerveződniük. A decentralizáció keretében Ukrajnában a korábban létező 490 járásból az összevonások révén 136 új járás alakult. Kárpátalja 13 járása helyén például mindössze 6 (Ungvári, Munkácsi, Beregszászi, Huszti, Técsői és Rahói) járás maradt, míg a korábbi 337 helyi önkormányzat 64 kistérségbe szerveződött a régióban (Csernicskó et al. 2021: 112-43).

A törvényileg elöírt közigazgatási összevonások kapcsán nemcsak a decentralizáció lexéma került be a Termini online szótárba, hanem a több korábbi települési önkormányzat egyesülése révén létrejött önkormányzati társulást megnevezö, egyébként szinonim kistérség, hromada/hromáda, illetve OTH/OTG szócikk is.

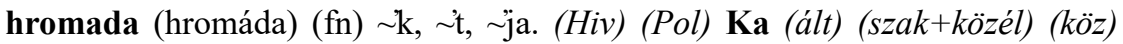
(ujj) kistérség, közigazgatási egység; egyesített területi közösség; az ukrajnai decentralizáció folyamán létrejött településtársulás Ka Magyar szempontból sikeresnek nevezte a hromadák kialakitásáról elfogadott tervezetet Barta József,

4 Lásd a Verhovna Rada szócikket a Termini magyar-magyar szótárban. 
a Kárpátaljai Megyei Tanács első helyettese, a KMKSZ alelnöke. (http://www. karpatalja.ma) Ka A politikus szerint a megyei adminisztráció által benyújtott kialakitási terv is kedvezö volt, de sikerült tovább böviteni a magyar érdekeltségü kistérségek számát, miután a szürtei és a kaszonyi hromada is megkapta a szükséges szavazatokat. (http://www.karpatalja.ma). [ukr громада 'ua'] ( $\rightarrow$ kistérség, OTG, OTH)

kistérség(fn) k, t, e. kistérség (fn) ek, et, e. (Hiv) (Pol) Ka (ált) (szak+közél) (köz) (új) közigazgatási egység; egyesített területi közösség; az ukrajnai decentralizáció folyamán létrejött településtársulás. Ka A decentralizációval foglalkozó szakemberek 2019-es mutatókat összegezve mérték fel az eddig megalakult kistérségek müködésének hatékonyságát. (https://kiszo.net). Ka Minden kistérségben folyamatban van a koronavirus elleni védöoltások beadása, ám a legtöbb helyen még mindig nagyon alacsony az oltakozási kedv. (https://karpatalja.ma). [az ukr громада 'ua' fordítása] ( $\rightarrow$ hromada, hromáda, OTG, OTH)

OTH [otehe] (fn) k, t, je. (Hiv) (Pol) Ka (id) (szak+sajtó) (köz) egyesített területi közösség; az ukrajnai decentralizáció folyamán létrejött településtársulás; kistérség Ka Február 3. és 14. között kényszerszünidöt vezetnek be a Munkácsi településtársulás (egyesitett területi közösség, OTH) területén. (http://life.karpat. in.ua). [ukr betüszó ОТГ, Об'єднана територіальна громада 'ua'] ( $\rightarrow$ OTG, hromada, kistéréség)

OTG [otege] (fn) k, t, je. (Hiv) (Pol) Ka (ált) (közél) (köz) (új) egyesített területi közösség; az ukrajnai decentralizáció folyamán létrejött településtársulás - Ka Az egyesitett territoriális hromadák $(O T G)$ - melyekböl jelenleg Ukrajnaszerte 640 alakult-, müködésének hatékonyságát Demjancsuk számokkal támasztotta alá. (https://karpathir.com). [ukr betüszó ОТГ, Об'єднана територіальна громада 'ua'] ( $\rightarrow$ OTH, hromada, kistérség)

A decentralizáció révén létrejött hromada/hromáda vagy kistérség, esetleg OTH/ OTG élén az önkormányzati választások keretében megválasztott tisztségviselő, a sztároszta vagy elöljáró áll.

sztároszta (fn) k, t, ja. (...) 4. (Hiv) Ka (ált) (közh) (köz) a decentralizáció néven emlegetett ukrajnai közigazgatási reform nyomán létrejött kistérségek választott vezetője, elöljárója Ka Természetesen ez a lista is módosulni fog, hiszen biztosan lehet tudni, hogy Petei Judit a KMKSZ megyei frakciójának lesz a tagja, s feltehetöen olyanok is lesznek, akik sztároszták maradnak az új közigazgatási rendszerben. https://kiszo.net). [or/ukr староста 'elöljáró, vezető' < or старейшина 'elöljáró'] ( $\rightarrow$ elöljáró)

elöljáró (fn) k, t, ja (Hiv) (Pol) Ka (ált) (közh) (köz) (új) a decentralizáció néven emlegetett ukrajnai közigazgatási reform nyomán létrejött kistérségek 
választott vezetője, elöljárója $\mathrm{Ka}$ Az emlitett önkéntes egyesülésről szóló törvény a községi elöljárónak (sztároszta) egyetlen közhatalmi funkciót határoz meg (https://www.umdsz.com.ua) [ukr староста 'ua' fordítása] ( $\rightarrow$ sztároszta)

A fenti példák alapján látható, hogy egyetlen új törvény akár nyolc új szó(jelentés) megjelenését eredményezheti a kárpátaljai magyar nyelvhasználatban, ez pedig akár nyolc új szócikk kialakítását vonhatja maga után a Termini online szótárban (decentralizáció, hromada, hromáda, kistérség, OTH, OTG, elöljáró, sztároszta). Hogy aztán a párhuzamosan használatos, szinonim hromada, hromáda, kistérség, OTH, OTG közül mely(ek) marad(nak) fenn hosszabb távon, csak az idő mutatja meg.

\section{A szótárban szereplő szóanyag társadalmi vonatkozásai}

Az ukrajnai forradalmak és politikai átrendeződések természetesen nemcsak a politikai terminológiában hagytak nyomot. Figyelemre érdemes például az országban zajló jogszabályi változások következtében megjelent új lexéma: a dekommunizáció.

Az ukrán декоммунізаиія lexéma a Szovjetunió Kommunista Pártja mint állampárt uralta szovjet korszakból megmaradt emlékmüvek, valamint település-, intézmény- és közterületi nevek eltüntetésének, felcserélésének folyamatát, illetve ennek a folyamatnak az eredményeit jelöli Ukrajnában. Maga a dekommunizáció egy 2015-ben elfogadott törvénycsomag alapján ment végbe, és egyrészt jelentős következményekkel járt, másrészt időnként megmosolyogtató közjátékok jellemezték (Fedinec-Csernicskó 2016a, 2016b; Csernicskó 2019: 189-205).

2015 októberében az Ukrán Nemzeti Emlékezet Intézete a dekommunizációs törvényekre hivatkozva közétett egy 520 nevet tartalmazó listát azokról a személyiségekről, akikről nem lehet intézményt, közterületet elnevezni Ukrajnában. ${ }^{5}$ A listában csak olyan személyek neve szerepelt, akikre az ukrajnai települések és közterek még bármilyen módon emlékeztettek. Így például rajta van a listán Lenin, illetve Marx és Engels is. Nincs viszont a listában Sztálin, akiről már rég nincs elnevezve semmi Ukrajnában.

A listában viszonylag kevés író, költő van. A törvény és a névsor alapján tehát Ukrajnában továbbra is szerepelhet közterület névadójaként például Makszim Gorkij és Vlagyimir Majakovszkij, akikről a 2012. évi CLXVII. számú, „egyes törvényeknek a XX. századi önkényuralmi rendszerekhez köthető elnevezések tilalmával összefüggő módosításáról" címet viselő törvény, ${ }^{6}$ pontosabban az ennek alapján készült akadémiai állásfoglalás ${ }^{7}$ szerint Magyarországon nem lehet közterületet elnevezni.

5 Список осіб, які підпадають під закон про декомунізацію. http://www.memory.gov.ua/ publication/spisok-osib-yaki-pidpadayut-pid-zakon-pro-dekomunizatsiyu

6 2012. évi CLXVII. törvény egyes törvényeknek a XX. századi önkényuralmi rendszerekhez köthető elnevezések tilalmával összefüggő módosításáról. http://mkogy.jogtar. $\mathrm{hu} /$ ?page $=$ show\&docid=a1200167.TV

7 Összefoglaló a XX. századi önkényuralmi rendszerekhez köthető elnevezésekkel összefüggő szakmai vizsgálatról. http://mta.hu/data/dokumentumok/hatteranyagok/akademiai szabalyozasok/osszefoglalalo_XX._szazadi_onkenyuralmi_rendszerek_b.pdf 
Mint ahogyan Ukrajnában nem tiltott az 1848/1849-es szabadságharc leverését ellenző orosz cári tisztet kitaláló kommunista író, Illés Béla neve sem. A kárpátaljai Beregszász városában még 2021 októberében is utca viseli a nevét.

Irodalmi kitalált személy is akad a tiltott nevek között: Pavel Korcsaginé, aki Nyikolaj Osztrovszkij Ahogy az acélt megedzik címü regényének hőse.

Egyetlen még élő személy szerepel a Nemzeti Emlékezet Intézete által összeállított névsorban: Valentyina Tyereskova, az első női ürhajós. A legfőbb ok, amiért oda került: 2014-ben szimbolikus szerepet vállalt a Krím Oroszország általi megszállását övező politikai propagandaakcióban.

A hosszú tiltólistában egyébként három magyar név található: Kun Béla, Zalka Máté és a kevésbé ismert Gavró Lajos neve. Kunról ez olvasható a listában: „A Krími Forradalmi Bizottság elnöke. A vörös terror megszervezője a Krímen." Zalka büne, hogy „részt vett a szovjet hatalom kiépítésében Ukrajnában”. ${ }^{9}$ Gavróról annyit jegyeznek meg, hogy „Kijev katonai parancsnoka a város bolsevik megszállása idején 1919-ben". ${ }^{10}$ A lista szerint van magyar vonatkozása Georgij Zsukov marsallnak is, az ő neve mellett indoklásként ugyanis egyebek mellett az is szerepel, hogy ,,a magyar forradalom egyik eltiprója 1956-ban". ${ }^{11}$

A Nemzeti Emlékezet Intézetének összesítése szerint az ország településeinek 3 százalékát kellett átnevezni a jogszabály értelmében. A2016. július 15-i állapot szerint összesen 987 város, nagyközség és falu, továbbá 25 járás kapott új nevet (Korolenko et al. 2017: 137). Ezek egy része azonban a de facto Oroszországhoz csatolt Krím félszigeten, illetve a kelet-ukrajnai szakadárok által ellenörzött területen található. ${ }^{12}$ Ezeknek a településeknek az átnevezésénél nem volt arra mód, hogy a helyi önkormányzatoktól kérjenek javaslatot az új névről, ezért a Nemzeti Emlékezet Intézete tett erröl javaslatot a parlamentnek (Korolenko et al. 2017: 137). Az más kérdés, hogy a Krím immáron orosz hatóságai vagy a donyecki és luhanszki szakadárok a legkevésbé sem foglalkoznak azzal, hogy Kijevben időközben átneveztek egyes járásokat, településeket. Kijev úgy hidalta át ezt a problémát, hogy az érintett területekre vonat-

8 Kun a tanácsköztársaság bukása utána a Szovjetunióba menekült, ahol kinevezték a Krími Forradalmi Bizottság elnökévé.

9 Zalka Máté (született Frank1 Béla) katona volt az első világháborúban, Doberdónál is harcolt az olasz fronton. 1916-ban orosz fogságba esett, és az 1917-es fordulat után a kommunizmus híve lett. Részt vett az oroszországi polgárháborúban. 1936-tól Lukács Pál tábornok néven a spanyolországi polgárháborúban harcolt a 12. nemzetközi brigád parancsnokaként, ahol 1937-ben elesett. A Doberdó címü regény írója. A szovjet korszakban a kárpátaljai Ungvár egyetlen magyar tannyelvü iskolája viselte a nevét (ma Dayka Gábor Középiskola).

${ }^{10}$ A Máramaros vármegyéből származó Gavró az első világháborúban orosz fogságba esett, ahol belépett a kommunista pártba. A vörösök oldalán részt vett az oroszországi polgárháborúban. Később különböző párt- és katonai megbízásokat teljesített, főként a Szovjetunió távol-keleti területein. Ahogyan Kun Béla, ő is a szovjet terror áldozata lett: 1937-ben letartóztatták, 1938-ban kivégezték.

${ }^{11}$ Zsukov a második világháború hősei közé tartozik, Leningrád felszabadítója, Berlin egyik elfoglalója.

12 Эксперты создали карту декоммунизации Украины. http://korrespondent.net/ ukraine/3536680-eksperty-sozdaly-kartu-dekommunyzatsyy-ukrayny 
kozó átnevezési döntések nem a kihirdetés napján lépnek hatályba, hanem majd csak a területek fölötti kontroll visszaszerzése után (Korolenko et al. 2017: 137).

A Nemzeti Emlékezet Intézete olyan útmutatókat, infografikákat is közzétett a honlapján, amelyek arról tájékoztatták a polgármestereket, hivatalnokokat, a közvéleményt, mi a módja a települések, közterületek vagy intézmények névváltoztatásának, összefoglalóan bemutatták a betiltott jelképeket. ${ }^{13} \mathrm{~A}$ közterületek (utcák, terek) átnevezését egy 150 oldalas informatív brosúra mutatta be lépésről lépésre. ${ }^{14}$ Ukrajna akkori elnöke, Petro Porosenko államfö bizakodva jelentette ki: nemzetbiztonsági érdek a dekommunizáció mielőbbi befejezése. ${ }^{15}$ Ennek ellenére nem minden település fogadta örömmel a gyakran csak felülről erőltetett átnevezést. E tekintetben tanulságos Dnyipropetrovszk város névváltoztatási hercehurcája.

A II. (Nagy) Katalin orosz cárnő uralkodása idején, a 18. század végén alapított település a Katerinoszláv (Катеринослав) nevet kapta. Azon a helyen azonban már korábban, a 17. században állt egy Kodak nevü erőd, amely a lengyel-litván nagyfejedelemség keleti határát jelző erődítmény volt. Rövid ideig (1798-1801 között) a település viselte a Novoroszijszk, illetve (1918-1919-ben) a környék kozák szicsekhez kapcsolódó törtére utaló Szicseszlav nevet is. E megszakításoktól eltekintve azonban 1784 és 1926 között Katerinoszláv volt a neve. A város a szovjet hatóságoktól kapta 1926-ban oroszul a Dnyepropetrovszk, ukránul a Dnyipropetrovszk nevet a Dnyeper folyóról, illetve Grigorij Petrovszkij szovjet-ukrán politikusról. Petrovszkij neve is szerepel azonban azoknak a történelmi személyiségeknek a sorában, akikről nem lehet semmit sem elnevezni Ukrajnában. ${ }^{16}$

Az Ukrajna legnagyobb folyója mellett elterülő megyeszékhely új nevének kiválasztása során több történelmi névvel is számolni kellett tehát, és ennek megfelelően számos névjavaslat merült fel. Ám kétségkívül a legeredetibb ötlettel a városi önkormányzat ${ }^{17}$ és Olekszandr Vilkul ${ }^{18}$ ellenzéki parlamenti képviselő állt elő. A Vilkul által a parlament elé törvénytervezetként beterjesztett elképzelés szerint ${ }^{19}$ Dnyipropetrovszk névváltoztatás utáni új megnevezése: Dnyipropetrovszk...

A javaslat lényege, hogy a város nevében előtagként megmarad a Dnyeper (ukránul Dnyipro) folyó neve, de a szovjet-ukrán politikus helyére (Szent) Péter (ukránul:

\footnotetext{
${ }^{13} \mathrm{https} / / /$ mega.nz/\#F!o5AVHawA!Q11QLpqpMmc41_ysUIY0RQ!0gJXBYDK

${ }^{14} \mathrm{http} / /$ www.memory.gov.ua/sites/default/files/perejmenuvannja-vulyc.pdf

${ }^{15}$ Порошенко: Декоммунизация должна быть завершена. http://korrespondent.net/ ukraine/3682845-poroshenko-dekommunyzatsyia-dolzhna-byt-zavershena

${ }^{16}$ Petrovszkij (1878-1958) ukrán családba született forradalmár, szovjet párt és közéleti személyiség volt. 1922-ben ukrán részről ő írta alá a Szovjetunió megalakulásáról szóló szerződést.

${ }^{17}$ Депутати змінили «інтимологію», щоб зберегти назву Дніпропетровську. http://www. pravda.com.ua/news/2015/12/29/7094054/

18 Вілкул пропонує перейменувати Дніпропетровськ у Дніпропетровськ. http://www. pravda.com.ua/news/2016/02/4/7097863/

19 Проект Постанови про збереження найменування міста Дніпропетровськ Дніпропетровської області (щодо зміни етимології найменування міста - визначення найменування міста Дніпропетровська за назвою ріки Дніпро та на честь Святого Апостола Петра). http://w1.c1.rada.gov.ua/pls/zweb2/webproc4_1?pf3511=58036
} 
Petro) apostol kerül. Azaz: a település neve továbbra is Dnyipropetrovszk marad ugyan, de név etimológiája módosul: Dnyipro + Petrovszkij helyett Dnyipro + (Szent) Péter/Petro apostol lett volna a névadó.

A Nemzeti Emlékezet Intézete a javaslat kapcsán így foglalt állást: „Valós párbeszédet kell folytatnunk a múltról. Ezek a játékok és trükkök a totalitarizmus véres öröksége körül istenkáromlás és sértés az áldozatok millióinak emléke előtt. A régi név elutasítása a történelmi név vagy egy új elnevezés keresését feltételezi, nem pedig a régi név új magyarázatának kitalálását.”20

Andrej Portnov történész a település neve kapcsán már korábban elindult vitát összefoglalva találóan jegyezte meg: ,jelzésértékü, mennyire nem beszélnek arról, a város orosz történelmét hogyan lehetne úgy integrálni a mai hivatalos narratívába, hogy az egyensúlyt teremtsen a valódi és képzelt, politikailag veszélyes tartalmak között; hogyan lehetne a katalini fejezetet (a kozák fejezettel együtt) a pillanatnyi politikai harc fegyveréböl turisztikai védjeggyé és a város sajátos történelmi emlékezetének elemévé alakítani. Nem kevésbé fontos, hogy [...] marginalizálva van a lengyel történelem, pedig a 17. században keletkezett Kodak, mint a Rzecz Pospolita legkeletibb erődítménye, ily módon tudná betölteni szerepét a régió »európaiságának« konstruálásában” (Portnov 2009: 38).

Végül egyébként hosszas vita után egy 2016. május 19-én hozott parlamenti határozat alapján Dnyipropetrovszk új neve - a folyóval azonos - Dnyipro lett. ${ }^{21}$

Más városok sem nyelték le némán az átnevezés kényszerét. Így például Kirovohrad (Кіровоград) lakossága is tiltakozott az ellen, hogy Kropivnickij (Кропивницький) lett az új neve. A helyi hatóságok a témában folytatott polémia során javasolták, hogy a település kapja vissza eredeti, az 1775-ös városalapításkor kapott és az 1924-es első átnevezésig viselt Єлисаветград (Jeliszavetgrád) nevet, amelyet a központi hatóságok azzal utasítottak el, hogy az a cári Oroszországra utal (Korolenko et al. 2017: 140). ${ }^{22}$

A kijevi hatalom - nem törődve az ellenkezéssel - parlamenti határozatokkal változtatta meg tehát az ellenálló települések nevét. Így 2016-tól a két említett megyeszékhely is új néven szerepel Ukrajna térképén. A két megye azonban maradt a régi nevén: Dnyipro városa továbbra is Dnyipropetrovszk megye (Дніпропетровська область), Kropivnickij pedig Kirovohrád megye (Кіровоградська область) székhelye. Hogy itt miért maradhatott meg a kommunista múlthoz kötődő név? Mert a megyék átnevezéséhez az alkotmányt is módosítani kell, amely - az ország közigazgatási felosztását meghatározó 133. cikkelyben - konkrétan megnevezi az ország megyéit, köztük Dnyipropetrovszk és Kirovohrád megyét is (Korolenko et al. 2017: 135). Az alkotmánymódosításhoz azonban máig nincs meg a kétharmados többség.

${ }^{20}$ http://www.memory.gov.ua/news/faq-use-shcho-vi-khotili-diznatisya-pro-dekomunizatsiyu

${ }^{21}$ Постанова Верховної Ради України № 1375-19 «Про перейменування міста Дніпропетровськ Дніпропетровської області» від 19.05.2016 p. http://zakon5.rada.gov. ua/laws/show/1375-19

22 В Кировограде митинги из-за переименования города. http://korrespondent.net/ ukraine/3608275-v-kyrovohrade-mytynhy-yz-za-pereymenovanyia-horoda 
A Magyarországgal szomszédos Kárpátalján is nyilvánosságra hozták a dekommunizációs törvény értelmében átnevezendő települések és közterületek listáját, ahol két település és 558 közterület megnevezése szerepelt. ${ }^{23} \mathrm{Az}$ egyik átnevezendö település, Komszomolszk az 1947-ig használt Nyimecka Mokra (Німецька Мокра/ Németmokra) helységnévhez tért vissza. A másik átnevezendő falu Zsovtneve (Жовтневе) község volt, amely eredetileg az 1917-es nagy októberi szocialista forradalomra utalva kapta a nevét; az ukrán жовтень (zsovteny) szó jelentése 'október', а жовтневе nagyjából azt jelenti: októberi. A helyi önkormányzat azonban megtagadta a névváltoztatást. Indoklásuk szerint a község nem az 1917-es pétervári fegyveres puccsról, hanem a helyi, jellegzetesen sárgás színű agyagos talajról kapta a nevét; a település neve így szerintük az ukrán жовтий (sárga) melléknévböl eredeztethetö. ${ }^{24} \mathrm{~A}$ megyei és kijevi vezetés azonban nem fogadta el az érvelést, így a falut ma már Zaberezs (Забереж) néven kell keresni a térképeken.

A dekommunizáció kapcsán az ukrán fővárostól távoli Kárpátalja az országos sajtóba is bekerült. Nagy érdeklődést váltott ki ugyanis, amikor Hennagyij Moszkal, Kárpátalja akkori kormányzója rendeleti úton az ukránul Калини, magyarul Alsókalina nevű községben a Lenin utcát a Beatles legendás tagjáról, John Lennonról nevezte el..$^{25}$ Leninből így lett a dekommunizáció révén Lennon.

Bár a dekommunizációs törvényböl nem következik, és a jogszabály alapján a Nemzeti Emlékezet Intézete által összeállított listában ennek megfelelően nem is szerepelnek a szovjet korszakhoz nem kötődő orosz történelmi vagy kulturális személyiségek nevei, Ukrajna megpróbálja az átnevezési hullámot és a dekommunizációt összekapcsolni a deruszifikációval és az ukránosítással. „A dekommunizáció folyamata $[\ldots]$ nem lesz teljesen sikeres a deruszifikáció és a dekolonalizáció folyamatának megkezdése nélkül” - véli például Tarsz Maruszik (2016).

Érdekes azonban, hogy - bár egyértelmúen kötődnek a szovjet rendszerhez és a kommunista múlthoz - nem kerültek tiltólistára Ukrajnában és Kárpátalján sem az olyan közterületi nevek, mint például a Partizán utca vagy a Borkanyuk utca, Vakarov utca. Ennek egyszerü oka van: a szovjet partizánok, illetve Borkanyuk ${ }^{26}$

${ }^{23}$ Перелік назв вулиць, провулків, площ тощо (у розрізі населених пунктів району, міста), визначених для перейменування. http://zakarpattya.net.ua/Blogs/143392-Dvasela-ta-558-vulyts-ploshch-i-provulkiv-na-Zakarpatti-maly-by-zminyty-nazvy

${ }^{24}$ Még mindig sok a szovjet rendszerhez köthető utcanév Kárpátalján. http://www. karpatalja.ma/karpatalja/kozelet/meg-mindig-sok-a-szovjet-rendszerhez-kotheto-utcanevkarpataljan/

${ }^{25} \mathrm{http}: / /$ www.moskal.in.ua/index.php?categoty=news\&news_id=2128. John Lennon nevét viseli ezentúl a Lenin utca egy kárpátaljai faluban. http:/www.karpatalja.ma/karpatalja/ kozelet/john-lennon-nevet-viseli-ezentul-a-lenin-utca-egy-karpataljai-faluban/

${ }^{26}$ Oleksza Borkanyuk (1901-1942) a Magyar Királyságban született, a mai Kárpátalja területéhez tartozó Körösmezőn. Amikor a régió Csehszlovákia része volt, a Szovjetunióban tanult. Rövid kitérők után 1941-ben tért vissza az akkor ismét Magyarországhoz tartozó Kárpátaljára, ahol partizánként, illetve a földalatti kommunista mozgalom egyik szervezőjeként müködött. 1942-ben a magyar katonai elhárítás egy partizánakció során elfogta. Egy budapesti börtönben halt meg. Miután Kárpátalja Szovjet-Ukrajna része lett, hamvait szülőföldjére szállították. 1965-ben megkapta a Szovjetunió Hőse címet. 
és Vakarov ${ }^{27}$ a második világháború éveiben a szovjetek oldalán részt vettek az akkor Magyarországhoz tartozó Kárpátalja elfoglalásáért vívott harcokban, az antifasiszta mozgalomban, azaz részei a Kárpátalja Szovjet-Ukrajnához csatolását legitimáló emlékezetpolitikának. Máig nem háborgatta senki például a Partizán utca és a Borkanyuk utca névtábláját Nagyszőlősön vagy a Vakarov utcáét Csapon. Egyébként az MTA fentebb idézett állásfoglalása szerint a partizán Magyarországon „nem használható közterület elnevezésére”, ugyanis ,,a kifejezés közvetlenül utal az önkényuralmi politikai rendszer kiépítését elősegítő idegen állam fegyveres erejére, a szovjet hadseregre és annak irreguláris katonai »szervezetére «". ${ }^{28}$

A dekommunizációs törvény hatását jól érzékeltetik ezek a számok: 1986 és 2013 között Ukrajnában összesen 591 település esett át névváltoztatáson (ebböl 138 kárpátaljai település volt); ${ }^{29}$ a dekommunizációról szóló törvény következményeként 2015 és 2016 között, gyakorlatilag egyetlen év alatt, 987 településnevet módosítottak az országban.

A dekommunizáció lexéma természetesen a dekommunizációt elöíró törvény elfogadását követően (szinte) azonnal megjelent a kárpátaljai magyar sajtóban és közbeszédben is.

\section{6. Összefoglalás}

A fent említett (és persze az adatbázisban szereplő, de itt nem említett) szavak Kárpátalján általában széles körben ismertek. A helyi magyar nyelvủ sajtóban (és onnan átvéve nem ritkán a magyarországi hírügynökségek közleményeiben) is gyakran megjelenő nyelvi elemek jól jelzik, milyen gyorsan változhat egy nyelv szókészlete. Arra is rávilágítanak azonban ezek a szavak, hogy - Szilágyi N. Sándor (2008: 106) megállapítása szerint - Trianon óta „a Kárpát-medencében a magyar nyelv nem egyetlen országban változik, hanem a történelem jelenlegi állása szerint most éppen nyolcban egyszerre, a nyelvi változást pedig minden országban más-más tényezők befolyásolják. Ennek következtében az egyes országokban a magyar nyelvnek sajátos változatai alakultak ki, amelyek, ha nem térnek is el egymástól annyira, hogy az emberek ne értenék meg továbbra is könnyüszerrel egymást, számos, viszonylag könnyen azonosítható jellegzetességet mutatnak. Emiatt szoktunk velük kapcsolatban nyelvi különfejlődésről is beszélni."

${ }^{27}$ Dmitro Vakarov (1920-1945) oroszul író költő a Magyar Királyságban született, a mai Kárpátalja területéhez tartozó Iza községben. Huszton és Prágában végezte a gimnáziumot, majd 1941-1944 között Budapesten volt egyetemi hallgató. Antifasiszta tevékenysége miatt 1944 áprilisában letartóztatták, Németországban halt meg. Halála után megkapta a „Harci Cselekményekért" kitüntetést, és posztumusz felvették a szovjet írószövetség tagjai közé.

${ }^{28}$ Összefoglaló a XX. századi önkényuralmi rendszerekhez köthető elnevezésekkel összefüggő szakmai vizsgálatról. http://mta.hu/data/dokumentumok/hatteranyagok/akademiai szabalyozasok/osszefoglalalo_XX._szazadi_onkenyuralmi_rendszerek_b.pdf

${ }^{29}$ Алфавітний покажчик нових і старих найменувань населених пунктів, які були перейменовані з 01.01.1986 по 01.02.2013. http:/static.rada.gov.ua/zakon/new/ADM/ d06.rtf 
Nem is oly régen, A magyar nyelv a Kárpát-medencében a XX. század végén címü könyvsorozat első kötetének sorozatszerkesztői elöszavában Kontra Miklós (1998: 13) még azt írta: „Tabut feszeget és méhkasba nyúl, aki a kisebbségben élő magyarok nyelvét kutatja a XX. század utolsó évtizedében [...], mert a magyar nyelvtudomány a Trianont követő hét évtizedben a kétnyelvüségbe került kisebbségi magyarok nyelvhasználatát nemigen vizsgálta tudományos objektivitással”. Azóta sok víz lefolyt a Kárpát-medence folyóin, és - részben épp az említett sorozat kötetei révén - ma már sokkal többet tudunk Trianon nyelvi következményeiröl. Mára már természetesnek fogadjuk el a nyelvi különfejlődés tényét. Ezt jelzi például, hogy abban a kötetben, ahol Szilágyi fentebb idézett tanulmánya megjelent, további öt szerző (Görömbei 2008; Veres 2008; Lanstyák 2008; Péntek 2008 és Csernicskó 2008) írásában is szó esik a nyelvi különfejlődésről.

A nyelvi különfejlödés kutatásának egyik fontos eredménye, hogy a magyar értelmező kéziszótár 2003-ban megjelent második, átdolgozott kiadásában (Pusztai szerk. 2003) már több olyan szó vagy szójelentés is szerepel, amelyek Magyarországon nem, csak a kisebbségi magyar régiókban élők nyelvhasználatában élnek (Beregszászi-Csernicskó 2004: 127-38). Az átdolgozott kéziszótárba mindössze 383 olyan szó került, amelyek a Magyarországon kívüli magyar nyelvváltozatok sajátos elemeit reprezentálják; ez a szótár a címszavainak 3 ezreléke: 250 szlovákiai szó mellett 91 romániai és 38 ukrajnai került be a szótárba (Kiss 2004). Azóta azonban a Magyarországon kívüli magyar nyelvváltozatok sajátos lexikai elemei közül több más szótárba is bekerült néhány (Csernicskó-Hires-Márku 2010: 91), így ezek a szótárak már nemcsak a magyarországi magyar, hanem valóban a magyar nyelv szótárai, és ezzel kezdetét vette a magyar nyelv határtalanítása (Tolcsvai Nagy 2018; Péntek 2018).

A Termini magyar-magyar szótára kiváló alátámasztása annak, hogy „,[a]z adminisztratív határok kialakulásuk után elkezdik befolyásolni a határon belül és azok másik oldalán beszélt nyelvváltozatokat. Mivel a határok meghatározzák a nyelvet beszélők szociális hálóit, a határon belüli kapcsolatok felerősödnek, a határon átnyúló kapcsolatok akadályokba ütköznek. Így az államhatárok kettős természetűek, mivel egyszerre idéznek elő konvergenciát és divergenciát: a határon belül beszélt változatok elkezdenek egymáshoz közeledni és a kiegyenlítődés irányába fejlődni, míg a határ másik oldalán beszélt változatok elkezdenek különfejlödni, sőt végül új nyelvvé alakulhatnak" (Palander-Riionheimo-Koisvisto 2018: 7). A magyarországi és határon túli magyar nyelvhasználat közötti eltérések tehát természetes nyelvi folyamatok szükségszerü következményei, amelyek azonban önmagukban nem fenyegetik a magyar nyelv egységét a Kárpát-medencében (Szilágyi 2008; Lanstyák 2008; Csernicskó 2003). Az angol, német, spanyol, francia, olasz nyelvváltozatok között jóval nagyobb eltérések vannak, mint a magyar nyelv különböző változatai között, mégsem szakadtak több különböző nyelvre. Persze azt is jól tudjuk, hogy ha a politikai érdekek úgy kívánják, akkor az egyes nyelvváltozatok közötti eltérések, akár a viszonylag csekélyek is, akár önálló irodalmi nyelvek kodifikálásához is vezethetnek, ami szükségszerüen együtt jár a különálló nemzeti identitások kialakulásával is (Kamusella 2015; Csernicskó 2020). Amíg azonban a határokon túli 
magyarok az egységes magyar nemzet részének tekintik magukat, és a magyar nyelv az identitásuk lényegi összetevője, a magyar nyelv egysége - az egyebek mellett a Termini magyar-magyar online szótári adatbázisa révén is dokumentált különbségek ellenére - fennmarad. Ahhoz azonban, hogy a magyar nyelv hosszú távon megőrizhető legyen a Kárpát-medence Magyarországon kívüli régióiban, sok mindenre szükség van. Egyebek mellett arra, hogy a szomszédos államok többségi nemzetei ne tereljék a nyelvi jogaik korlátozásával az asszimiláció felé a területükön élő magyar kisebbségi közösségeket.

\section{SZAKIRODALOM}

Benő Attila - Péntek János (szerk.) 2011. A Termini Magyar Nyelvi Kutatóhálózat tíz éve. Gramma Nyelvi Iroda - Szabó T. Attila Nyelvi Intézet, Dunaszerdahely-Kolozsvár.

Benő Attila - Juhász Tihamér - Lanstyák István 2020. A Termini „,határtalan” szótára. Magyar Tudomány 181/2: 153-63. https://doi.org/10.1556/2065.181.2020.2.2

Beregszászi Anikó 1997. Kárpátaljai szavak a Magyar Értelmező Kéziszótárban? Pánsíp V/2: 24-7.

Beregszászi Anikó - Csernicskó István 2004. ...itt mennyit ér a szó? Írások a kárpátaljai magyarok nyelvhasználatáról. PoliPrint, Ungvár.

Csernicskó István 2003. A nyelvi egységről és a nyelvi különfejlődésről. In: Csernicskó István (szerk.): A mi szavunk járása. Bevezetés a kárpátaljai magyar nyelvhasználatba. PoliPrint, Ungvár, 251-8.

Csernicskó István 2008. Nyelv és azonosságtudat összefüggései a kárpátaljai magyar közösségben. In: Fedinec Csilla (szerk.): Értékek, dimenziók a magyarságkutatásban. Magyar Tudományos Akadémia Magyar Tudományosság Külföldön Elnöki Bizottság, Budapest, $153-70$.

Csernicskó István 2019. Fények és árnyak: Kárpátalja nyelvi tájképéből. Autdor-Shark, Ungvár.

Csernicskó István 2020. A verbális repertoár elemeinek osztályozása nyelvpolitikai nézőpontból: az északi szláv dialektuskontinuum kárpátaljai szakaszának példája. In: Heltai János Imre - Oszkó Beatrix (szerk.): Nyelvi repertoárok a Kárpát-medencében és azon kivül. Nyelvtudományi Intézet, Budapest, 44-74.

Csernicskó István - Hires Kornélia - Márku Anita 2010. A szókölcsönzés. In: Csernicskó István (szerk.): Megtart a szó. Hasznositható ismeretek a kárpátaljai magyar nyelvhasználatról. MTA-Hodinka Antal Nyelvészeti Kutatóintézet, Budapest-Beregszász, 82-93.

Csernicskó István - Hires-László Kornélia - Karmacsi Zoltán - Márku Anita - Máté Réka Tóth-Orosz Enikő 2021. A magyarok és a Magyar nyelv Kárpátalján. Termini Egyesület, Törökbálint.

Fedinec Csilla - Csernicskó István 2016a. Az Ukrajnából számüzött Lenin. Európai út a kommunizmus öröksége nélkül? Regio 24/1: 73-124. https://doi.org/10.17355/rkkpt. v24i1.96

Fedinec Csilla - Csernicskó István 2016b. Декоммунизация в современной Украине: поиск путей в области истории, идентичности и языковой политики. Историческая Экспертиза 4: 67-88.

Görömbei András 2008. A magyar nyelv erdélyi helyzete és perspektívái. In: Fedinec Csilla (szerk.): Értékek, dimenziók a magyarságkutatásban. MTA Magyar Tudományosság Külföldön Elnöki Bizottság, Budapest, 136-52.

Kamusella, Tomasz 2015. Creating Languages in Central Europe During the Last Millennium. Palgrave Macmillan, New York. https://doi.org/10.1057/9781137507846 
Kiss Jenő 2004. Egy régi-új nyelvi sikerkiadvány: a Magyar értelmező kéziszótár. Magyar Tudomány 5: 670-3.

Kontra Miklós 1998. Sorozatszerkesztői előszó. In: Csernicskó István 1998. A magyar nyelv Ukrajnában (Kárpátalján). Osiris Kiadó - MTA Kisebbségkutató Műhely, Budapest, 13-5.

Korolenko, Bohdan - Karetnyikov, Igor - Majorov, Makszim 2017. Декомунізація назв населених пунктів та районів України: підстави, процес, підсумки. Micmo: icmopiя, культура, суспільство 1: 134-41.

Lanstyák István 2008. A magyar szókészlet szétfejlődése 1918 után. In: Fedinec Csilla (szerk.): Értékek, dimenziók a magyarságkutatásban. MTA Magyar Tudományosság Külföldön Elnöki Bizottság, Budapest, 118-35.

Lanstyák István - Benő Attila - Juhász Tihamér 2011. A Termini magyar-magyar szótár és adatbázis. In: Benő Attila - Péntek János (szerk.): A Termini Magyar Nyelvi Kutatóhálózat tíz éve. Gramma Nyelvi Iroda - Szabó T. Attila Nyelvi Intézet, DunaszerdahelyKolozsvár, 340-58.

Maruszik, Tarasz 2016. День слов'янської писемності і культури: декомунізація буде неповна без дерусифікації. Портал мовної політики, http://language-policy. info/2016/06/den-slov-yanskoji-pysemnosti-i-kultury-dekomunizatsiya-bude-nepovnabez-derusyfikatsiji/

Palander, Marjatta - Riionheimo, Helka - Koisvisto, Vesa 2018. Introduction: Creating and Crossing Linguistic Borders. In: Palander, Marjatta - Riionheimo, Helka - Koisvisto, Vesa (eds.): On the Border of Language and Dialect. Finnish Literature Society, Helsinki, 7-15. https://doi.org/10.21435/sflin.21

Péntek János 2009. Termini: The Network of Hungarian linguistic Research Centres in the Carpathian Basin. Minorities Research 11: 97-123.

Péntek János 2018. A külső régiók. In: Tolcsvai Nagy Gábor (szerk.): A magyar nyelv jelene és jövője. Gondolat Kiadó, Budapest, 179-98.

Portnov, Andrej 2009. Történelemírás ukrán módra. Megjegyzések a hétköznapi valóság történeti alapú átrendezéséhez. In: Fedinec Csilla - Szereda Viktória (szerk.): Ukrajna színeváltozása 1991-2008. Politikai, gazdasági, kulturális és nemzetiségi attitüdök. Kalligram Kiadó, Pozsony, 11-49.

Pusztai Ferenc (szerk.) 2003. Magyar értelmező kéziszótár. Második, átdolgozott kiadás. Akadémiai Kiadó, Budapest.

Szilágyi N. Sándor 2008. A magyar nyelv a Magyarországgal szomszédos országokban. In: Fedinec Csilla (szerk.): Értékek, dimenziók a magyarságkutatásban. MTA Magyar Tudományosság Külföldön Elnöki Bizottság, Budapest, 105-17.

Tolcsai Nagy Gábor (szerk.) 2007. Idegen szavak szótára. Osiris Kiadó, Budapest.

Tolcsvai Nagy Gábor 2018. Az anyaország és a külső régiók, a határtalanítás. In: Tolcsvai Nagy Gábor (szerk.): A magyar nyelv jelene és jövője. Gondolat Kiadó, Budapest, 150-63.

Veres Valér 2008. A Kárpát-medencei magyarok nemzeti és állampolgári identitásának fő sajátosságai. In: Fedinec Csilla (szerk.): Értékek, dimenziók a magyarságkutatásban. MTA Magyar Tudományosság Külföldön Elnöki Bizottság, Budapest, 35-60.

Csernicskó István

egyetemi tanár

II. Rákóczi Ferenc Kárpátaljai

Magyar Főiskola és Pannon Egyetem

https://orcid.org/0000-0003-4512-988X
Márku Anita

egyetemi docens

II. Rákóczi Ferenc Kárpátaljai Magyar

Főiskola Hodinka Antal Nyelvészeti

Kutatóközpont

https://orcid.org/0000-0001-8976-117X 


\section{SUMMARY}

Csernicskó, István; Márku, Anita

\section{Samples of the Subcarpathian material of the Termini Hungarian-Hungarian dictionary}

The paper gives a foretaste of the Subcarpathian material of the Termini Hungarian-Hungarian dictionary, showing how close correlations can be seen between social and political changes occurring in Hungarian-speaking regions outside Hungary and the extension of the material of that online dictionary. The analysis points out that the varieties of Hungarian in the surrounding countries necessarily exhibit divergent developments in an intimate relationship with the social, political, economic, and cultural state of affairs observable in the individual countries. The authors also draw the readers' attention to the fact that a number of loanwords are used in the Hungarian varieties of the neighbouring countries that are known in several regions, rather than in just one, and that some of these are also included and exemplified in the online dictionary.

Keywords: Termini dictionary, Subcarpathia, word borrowing, language and society, online dictionary 